\title{
TRADE COSTS, TIME, AND SUPPLY CHAIN RELIABILITY
}

Utsav Kumar, Ben Shepherd, and Roselle Dime

NO. 56

June 2018
ADB SOUTH ASIA WORKING PAPER SERIES 


\section{ADB South Asia Working Paper Series}

\section{Trade Costs, Time, and Supply Chain Reliability}

Utsav Kumar, Ben Shepherd, and Roselle Dime

No. 56 | June 2018
Utsav Kumar is country economist, Sri Lanka Resident Mission, South Asia Department, Asian Development Bank (ADB). Ben Shepherd is the principal of Developing Trade Consultants. Roselle Dime is a consultant at $\mathrm{ADB}$.

The authors thank Rosalind McKenzie, Masato Nakane, and Sonoko Sunayama of ADB, and Yann Duval of the United Nations Economic and Social Commission for Asia and the Pacific for useful comments and suggestions. 
(C) 2018 Asian Development Bank

6 ADB Avenue, Mandaluyong City, 1550 Metro Manila, Philippines

Tel +63 2632 4444; Fax +6326362444

www.adb.org

Some rights reserved. Published in 2018.

ISSN 2313-5867 (print), 2313-5875 (electronic)

Publication Stock No. WPS189387-2

DOI: http://dx.doi.org/10.22617/WPS189387-2

The views expressed in this publication are those of the authors and do not necessarily reflect the views and policies of the Asian Development Bank (ADB) or its Board of Governors or the governments they represent.

ADB does not guarantee the accuracy of the data included in this publication and accepts no responsibility for any consequence of their use. The mention of specific companies or products of manufacturers does not imply that they are endorsed or recommended by ADB in preference to others of a similar nature that are not mentioned.

By making any designation of or reference to a particular territory or geographic area, or by using the term "country" in this document, $A D B$ does not intend to make any judgments as to the legal or other status of any territory or area.

This work is available under the Creative Commons Attribution 3.0 IGO license (CC BY 3.0 IGO)

https://creativecommons.org/licenses/by/3.0/igo/. By using the content of this publication, you agree to be bound by the terms of this license. For attribution, translations, adaptations, and permissions, please read the provisions and terms of use at https://www.adb.org/terms-use\#openaccess.

This CC license does not apply to non-ADB copyright materials in this publication. If the material is attributed to another source, please contact the copyright owner or publisher of that source for permission to reproduce it. $A D B$ cannot be held liable for any claims that arise as a result of your use of the material.

Please contact pubsmarketing@adb.org if you have questions or comments with respect to content, or if you wish to obtain copyright permission for your intended use that does not fall within these terms, or for permission to use the ADB logo.

The ADB South Asia Working Paper Series is a forum for ongoing and recently completed research and policy studies undertaken in $\mathrm{ADB}$ or on its behalf. It is meant to enhance greater understanding of current important economic and development issues in South Asia, promote policy dialogue among stakeholders, and facilitate reforms and development management.

The ADB South Asia Working Paper Series is a quick-disseminating, informal publication whose titles could subsequently be revised for publication as articles in professional journals or chapters in books. The series is maintained by the South Asia Department. The series will be made available on the ADB website and on hard copy.

Notes:

In this publication, “\$” refers to United States dollars.

Corrigenda to ADB publications may be found at http://www.adb.org/publications/corrigenda. 


\section{CONTENTS}

TABLES AND FIGURES Iv iv

ABSTRACT

$\begin{array}{ll}\text { I. INTRODUCTION } & 1\end{array}$

II. DATA AND PRELIMINARY ANALYSIS $\quad 2$

A. Time and Uncertainty Data 2

B. Trade Costs Data

C. Other Data

D. Preliminary Analysis $\quad 6$

$\begin{array}{llr}\text { III. } & \text { ECONOMETRIC MODEL AND RESULTS } & 8\end{array}$

IV. CONCLUSION AND POLICY IMPLICATIONS

$\begin{array}{ll}\text { REFERENCES } & 14\end{array}$ 


\section{TABLES AND FIGURES}

\section{TABLES}

1 Variables, Definitions, and Sources 5

2 Summary Statistics (bilateral sample) $\quad 8$

3 Correlation Matrix (bilateral sample) 9

4 Regression Results (bilateral sample) 10

5 Summary Statistics (country sample) 11

6 Regression Results (country sample) 12

\section{FIGURES}

1 Percentage of Shipments Meeting Internal Quality Criteria, South Asia Subregional Economic Cooperation countries and comparator countries, 2016

2 Coefficient of Variation for Deliveries from South Asia Subregional Economic Cooperation countries and comparators to the People's Republic of China (index, latest available year)

3 Correlation between Median Trade Time and Trade Costs (latest available year, all countries) 7

4 Correlation between Standard Deviation of Trade Time and Trade Costs (latest available year, all countries) 


\begin{abstract}
This paper uses measures of international transport time, in median and standard deviation, based on shipment-level data from the Universal Postal Union, to analyze the effect of time on trade costs. We find robust evidence that median shipping times increase trade costs by a substantial amount. The evidence for uncertainty, as measured by the standard deviation of shipment time, is contrary to expectations, likely due to problems recording data on the ground. We also analyze the determinants of shipping times and find that geographical distance is the most reliable indicator of median time and uncertainty, with logistics performance, as measured by the World Bank's Logistics Performance Index, also playing a role in determining shipment times. South Asia Subregional Economic Cooperation countries could benefit from investing additional resources in improving connectivity and thereby reducing transport times and increasing reliability to major markets.
\end{abstract}





\section{INTRODUCTION}

1. Most first-generation trade facilitation indicators, such as the World Bank's doing business dataset, focus on average characteristics of supply chains, such as average time or cost involved in export or import transactions (e.g., Djankov, Freund, and Pham 2010). However, businesses involved in the activity of moving goods around the world frequently indicate informally that, although it is desirable to reduce average times and costs, the main factor impacting their performance is, in fact, reliability. If it takes 10 days (with a maximum of 10.5 days and a minimum of 9.5 days) to move goods from one country to another, businesses can plan their processes accordingly. However, for the same average time but a range of $+/-5$ days, they need to adopt costly hedging strategies such as maintaining inventories or adding redundancies into their supply chains to deal with uncertainty on one bilateral linkage. As a result, performance and competitiveness suffer. Moreover, multinational enterprises looking to establish productive units will be influenced not only by average trade times and costs, but also by supply chain reliability.

2. Newer trade facilitation indicators, such as the World Bank's Logistics Performance Index (LPI), take into account this issue. The domestic part of the LPI survey asks logistics operators to identify the percentage of shipments that meet their own internal quality criteria, which take into account unexpected delays in shipping, as well as losses due to various causes, including theft and problems with supply chain governance. Similarly, the international part of the LPI survey asks logistics operators abroad to rank the timeliness of delivery across countries; however, it is based on professionals' perceptions, not hard data on times.

3. Figure 1 shows how the South Asia Subregional Economic Cooperation (SASEC) countries perform on this metric, by comparing them with selected countries in East Asia and Southeast Asia. Although differences are, in some cases, not large, there is clear evidence of superior performance in East Asia and

Figure 1: Percentage of Shipments Meeting Internal Quality Criteria, South Asia Subregional Economic Cooperation countries and comparator countries, 2016

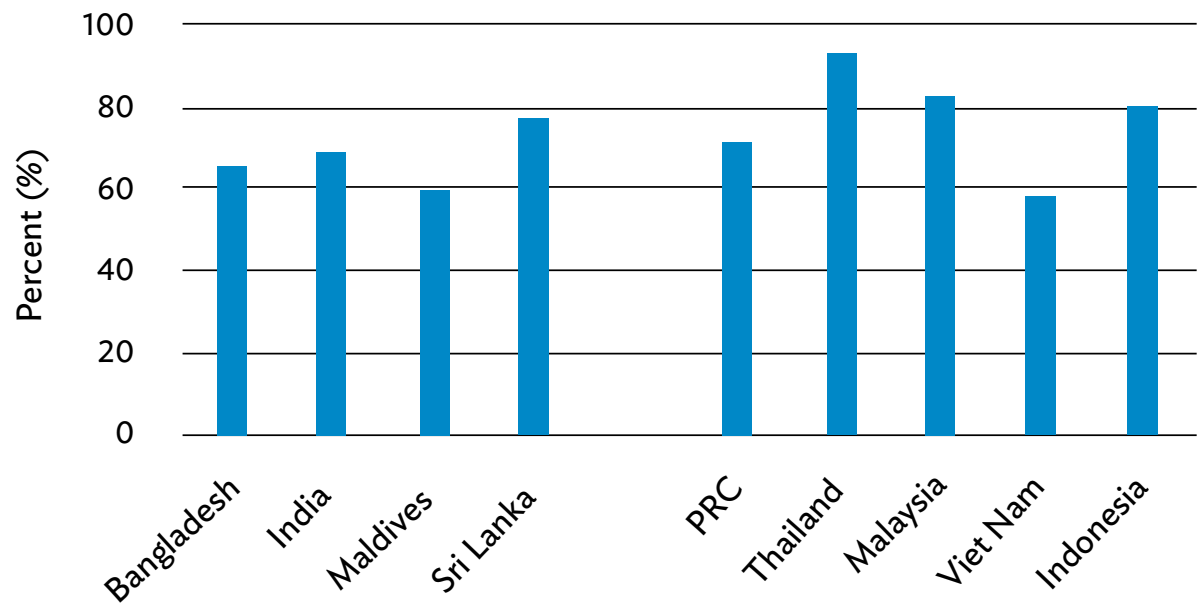

PRC $=$ People's Republic of China.

Note: Data not available for Bhutan, Myanmar, and Nepal.

Source: World Bank. Logistics Performance Index. 
Southeast Asia. Shipments in those locations, which are also major hubs for production within global value chains (GVCs), tend to take place with a higher degree of certainty than in SASEC countries, where GVCs are still in the early stages of development. To be clear, reliability of delivery is not the only factor that holds back GVC development in SASEC countries. Trade and investment policies also play an important role, but these data suggest that the reliability dimension of trade facilitation may be an under-examined issue.

4. Indeed, in the international trade literature in general, the role of reliability as a determinant of trade flows has not been examined rigorously until recently, due largely to lack of data. The first contribution directly on point is Anson et al. (2017). Anson et al. used shipment-level data on parcel flows from the Universal Postal Union (UPU) to construct measures of the uncertainty associated with international shipment times, in addition to average shipment times themselves. In a standard gravity model, they found evidence that uncertainty negatively impacts bilateral trade over and above any effects stemming from longer average times. They also found indications that the effect is more pronounced as time delays become longer. By breaking down their sample into North-North, North-South, and SouthSouth parcel flows, they have shown that uncertainty is of greatest relative importance to North-North trade, while average times tend to have a greater impact on trade in the other directions.

5. We build on and extend this work by looking at the impact of trade times and uncertainty on trade costs. To do this, we use the data in Anson et al. (2017), and combine it with data from the United Nations Economic and Social Commission for Asia and the Pacific (UNESCAP)-World Bank Trade Costs Database (Arvis et al. 2016). We conduct regressions at the bilateral (country pair level), as well as at the level of aggregate countries, and control for the typical historical and geographical factors that are known to influence trade costs. Our results allow us to estimate the extent to which SASEC countries could reduce trade costs if they improved reliability to a benchmark level. Given that trade costs drive a wedge between producer and consumer prices in a way that can reduce welfare, they are a more telling indicator of the economic costs of poor reliability and trade facilitation than are observed differences in trade flows.

6. We also turn the data on its head to look at the determinants of international transport times and uncertainty, in a way analogous to Hillberry and Zhang (2015). Although results for this part of the analysis are weaker, there are nonetheless significant indications that logistics performance is a statistically significant predictor of the time taken for international transport, even after controlling for other factors.

\section{DATA AND PRELIMINARY ANALYSIS}

\section{A. Time and Uncertainty Data}

7. Anson et al. (2017) described their data on international trade times in detail. As the dataset is not well known, we repeat the salient aspects here.

8. The Postal Technology Center (PTC) of the UPU collects detailed information on international postal flows. Based on scanning procedures, the PTC created the Express Mail Service item Event (EMSEVT) event messaging system. Originally, EMSEVT was developed to ensure the traceability of postal items around the world. Postal operators exchange messages containing information about every postal item that circulates in the international postal network. Based on a unique tracking number identifier, the dispatching and recipient countries communicate about events occurring to the item for three mail classes: parcels (up to 30 kilograms), express deliveries, and letters (up to 2 kilograms). Our analysis uses the data on parcel flows only, as it has the closest correspondence with trade transactions. 
For example, Anson, Boffa, and Helble (2014) found a strong statistical correlation between parcel flows and international trade flows for the same commodity groups.

9. Every parcel that is sent internationally through the UPU system is scanned up to 12 times, from the posting of the parcel at the local post office to the final delivery. Each scan records the exact time of the event. The EMSEVT event takes the following form:

1. Posting/Collection (EMA)

2. Arrival at outward office of exchange (EMB)

3. Departure from outward office of exchange (EMC)

4. Arrival at inward office of exchange (EMD)

5. Handed over to Customs (EME)

6. Departure from inward office of exchange (EMF)

7. Arrival at delivery office (EMG)

8. Unsuccessful delivery (EMH)

9. Final delivery (EMI)

10. Arrival at transit office of exchange (EMJ)

11. Departure from transit office of exchange (EMK)

10. Conceptually, there are three broad categories of events. The first segment involves all the information about the exporting procedure, from posting (EMA) at the local post office to departure from the office of exchange (EMC). The second category refers to events concerning distribution in the destination country: from arrival at the inward office of exchange (EMD), passing through customs (EME, EMF), up to distribution and final delivery (EMG to EMI). The third category refers to items that need an intermediate operator to reach the final destination (EMJ, EMK).

11. In this paper, we are concerned with international shipping times, i.e., the difference between events EMC and EMD in the EMSEVT structure. Anson et al. (2017) explore the data in detail and explain treatment methodologies. In additional results for that paper, available on request, the authors have shown that international parcel flows fit the gravity model well. This definition captures international transit time, in the sense of the amount of time taken between departure from the sending country's postal system to arrival in the recipient country's postal system. Concretely, our measure includes the time taken to move parcels from one country to another by sea, air, or in some cases, land. This element of our measurement of time introduces an important novelty into the literature, while our shipmentlevel unit of analysis makes it possible to go further than other work in describing the full distribution of shipment times.

12. The UPU shipments dataset is very large. We start with 260 million observations, as our unit of analysis is the individual shipment. Indeed, that initial figure is already based on a restriction: we consider only observations delivered between May 2013 and April 2014. There is a considerable amount of noise in the raw data, so we adopted a number of cleaning procedures. First, we selected only the tracking numbers that belong to international parcels. ${ }^{1}$ Second, we only kept observations for which the recorded EMSEVT are chronological in the order set out above. We kept observations with some missing events but with the remainder of the message chain in chronological order. Third, we checked for the uniqueness of tracking numbers as postal operators reuse old tracking numbers after a few years. Whenever a duplicate tracking number was found, only the one with an EMD event recorded between 2013 and 2014 was kept. Our cleaning procedures do have a significant impact on data availability, reducing the effective sample from essentially all countries in the world, to 160 exporters and 119 importers.

We have three mail classes in the raw data (international letters, international express mail, and international parcels). 
13. To be able to relate the postal shipments data to trade flows, we need to work at the aggregate level. We therefore compute two time-relevant measures. The first, the sample median of the time (mediantime) between events EMC and EMD by (directional) country pair, is designed to capture the central tendency in the data. It is analogous to time variables used in previous research, which use one number - typically a schedule or consensus estimate- to summarize trading times. The main innovation of this paper on the data side, like Anson et al. (2017), is to supplement the median with the standard deviation of international shipments times by (directional) country pair. The standard deviation (sdtime) provides an indication of the uncertainty affecting shipments from one country to another. In undertaking the analysis, we are aware that the UPU data mix transport modes according to country characteristics and export product mix, which necessarily introduces substantial noise into the data, in addition to what is already there due to inconsistent scanning practices on the ground.

14. Although the UPU dataset is confidential and we cannot report full results by country, we can present some indicative measures to put the performance of SASEC countries in perspective. Figure 2 presents a modified coefficient of variation (standard deviation divided by median) for international shipment times from SASEC countries and comparators to the People's Republic of China (PRC). Data are not available for those countries not included in the figure, and Bhutan reports a standard deviation of zero, which is implausible. Figures vary widely across countries, but in relative terms, variability is often higher in the comparator countries than in SASEC countries, even for Viet Nam, which is geographically contiguous to the PRC. Thailand, on the other hand, has relatively low variability. Data for Bhutan (already discussed) and Myanmar need to be interpreted cautiously due to the relatively small number of shipments compared with countries such as India. Although there are concerns about the quality of these data, they suggest that SASEC countries may be relatively well placed in terms of delivery time variability, although this information needs to be taken in the context of the LPI discussion above.

\section{Figure 2: Coefficient of Variation for Deliveries from South Asia Subregional Economic Cooperation countries and comparators to the People's Republic of China}

(index, latest available year)

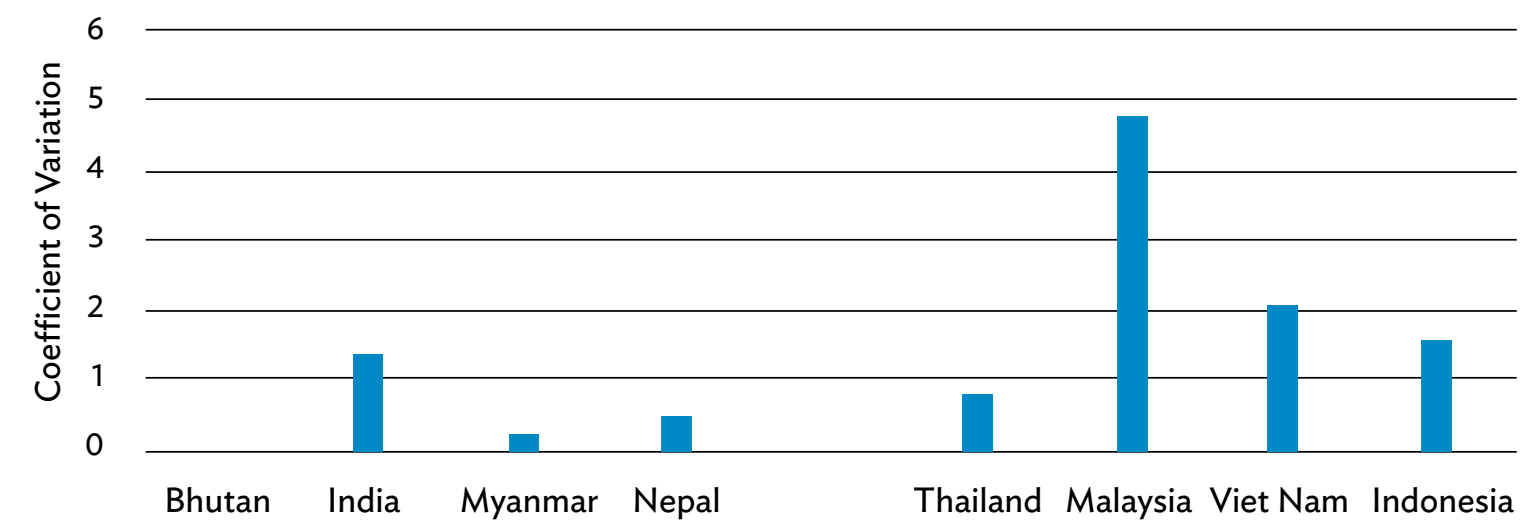

Note: Data not available for Bangladesh, Maldives, and Sri Lanka.

Source: Authors' calculations. 


\section{B. Trade Costs Data}

15. In addition to the UPU data on trade times and uncertainty, we also use the UNESCAP-World Bank dataset on trade costs. Arvis et al. (2016) set out the data collection and treatment methodology in full. In essence, theoretical results are used to infer the level of international relative to intranational trade costs, based on the observed pattern of trade and production. Keeping all other factors constant, if a country starts to trade relatively more with other countries than with itself, it must be because international trade costs have fallen. Trade costs are expressed in index form, as an ad valorem equivalent, but each figure represents the geometric average of trade costs from exporter to importer and from importer to exporter, deflated by internal trade costs in both countries. We take trade costs for total trade, aggregating across all sectors.

\section{Other Data}

16. Table 1 presents a complete list of data and sources used in the regressions. In addition to the two discussed in detail above, we also use standard sources for controls (such as per capita income), and logistics performance.

\section{Table 1: Variables, Definitions, and Sources}

\begin{tabular}{|c|c|c|}
\hline Variable & Definition & Source \\
\hline RTA & $\begin{array}{l}\text { Dummy variable equal to unity for country pairs that are members } \\
\text { of the same regional trade agreement }\end{array}$ & De Sousa (2014) \\
\hline Common Border & $\begin{array}{l}\text { Dummy variable equal to unity for country pairs that share a com- } \\
\text { mon border }\end{array}$ & CEPII \\
\hline Language & $\begin{array}{l}\text { Dummy variable equal to unity for country pairs that share a com- } \\
\text { mon language }\end{array}$ & CEPII \\
\hline Colony & $\begin{array}{l}\text { Dummy variable equal to unity if one country in a pair was once a } \\
\text { colony of the other }\end{array}$ & CEPII \\
\hline Common Colonizer & $\begin{array}{l}\text { Dummy variable equal to unity if the two countries in a pair were } \\
\text { once colonized by the same country }\end{array}$ & CEPII \\
\hline Same Country & $\begin{array}{l}\text { Dummy variable equal to unity if the two countries in a pair were } \\
\text { once part of the same country }\end{array}$ & CEPII \\
\hline Log(Distance) & $\begin{array}{l}\text { Logarithm of the great circle distance between the main cities in } \\
\text { the exporting and importing countries }\end{array}$ & CEPII \\
\hline Log(Median Time) & $\begin{array}{l}\text { Logarithm of the median international transport time reported } \\
\text { for parcel shipments from the exporting country to the importing } \\
\text { country }\end{array}$ & UPU \\
\hline Log (SD Time) & $\begin{array}{l}\text { Logarithm of the standard deviation of international transport } \\
\text { times reported for parcel shipments from the exporting country } \\
\text { to the importing country }\end{array}$ & UPU \\
\hline Log(GDP per capita) & Logarithm of GDP per capita (in constant PPP dollars) & WDI \\
\hline Landlocked & $\begin{array}{l}\text { Dummy variable if importing country in the UPU data is landlocked } \\
\text { for country-level regressions }\end{array}$ & CEPII \\
\hline Island & $\begin{array}{l}\text { Dummy variable if importing country in the UPU data is an island } \\
\text { country for country-level regressions }\end{array}$ & \\
\hline $\log (\mathrm{LPI})$ & Logarithm of Logistics Performance Index (LPI) & WDI \\
\hline Log(Average Distance) & $\begin{array}{l}\text { Logarithm of the average (by importer) of the great circle distance } \\
\text { between the importing country and all countries in the world } \\
\text { (including those not covered in the UPU data) }\end{array}$ & $\begin{array}{l}\text { Authors' calculation } \\
\text { using UPU data }\end{array}$ \\
\hline
\end{tabular}


Table 1: continued

\begin{tabular}{lll}
\hline \multicolumn{1}{c}{ Variable } & \multicolumn{1}{c}{ Definition } & Source \\
\hline Ave. Median & $\begin{array}{l}\text { Average (by importer) of the median international transport time } \\
\text { reported for parcel shipments by the importing country from each } \\
\text { of the source (exporting) country }\end{array}$ & $\begin{array}{l}\text { Authors' calculation } \\
\text { using UPU data }\end{array}$ \\
\hline Ave. SD & $\begin{array}{l}\text { Average (by importer) of the standard deviation of international } \\
\text { transport times reported for parcel shipments by the importing } \\
\text { country from each of the source (exporting) country }\end{array}$ & Authors' calculation \\
& $\begin{array}{l}\text { GDP weighted average (by importer) of the median international } \\
\text { transport time reported for parcel shipments by the importing } \\
\text { country from each of the source (exporting) country, weights being } \\
\text { the GDP weights of the source country }\end{array}$ & Authors' calculation \\
\hline W. Ave. Median & $\begin{array}{l}\text { GDP weighted average (by importer) of the standard deviation of } \\
\text { international transport times reported for parcel shipments by the } \\
\text { importing country from each of the source (exporting) country, }\end{array}$ & Authors' calculation \\
& weights being the GDP weights of the source country & \\
\hline W. Ave. SD & &
\end{tabular}

Ave = average, $\mathrm{CEPII}=$ Centre d'Études Prospectives et d'Informations Internationales, GDP = gross domestic product,

LPI = Logistics Performance Index, PPP = purchasing power parity, RTA = regional trade agreement, SD = standard deviation,

$\mathrm{UPU}=$ Universal Postal Union, $\mathrm{W}$. Ave = weighted average, $\mathrm{WDI}=$ World Development Indicators.

Source: Author's calculations.

\section{Preliminary Analysis}

17. Our contention in this paper is that the uncertainty associated with international trade transactions adds to trade costs. To provide some preliminary evidence on the question, Figures 3 and 4 look at the correlations between our trade time variables, and trade costs. In Figure 3, there is a clear positive association, as we would expect, between median trade time and trade costs. Although there is considerable dispersion around the line of best fit, the relationship is clearly upward sloping, which means that higher trade times tend to be associated with higher trade costs. By contrast, Figure 4 is much weaker: there is no obvious association between trade time uncertainty and trade costs. The dominant feature of this graph is its dispersion. We therefore conclude that although there seems to be a prima facie relationship between median trade times and trade costs, the same is not true for uncertainty. Of course, this conclusion is based on simple bivariate correlations, and may change once we implement a fully specified econometric model. 
Figure 3: Correlation between Median Trade Time and Trade Costs (latest available year, all countries)

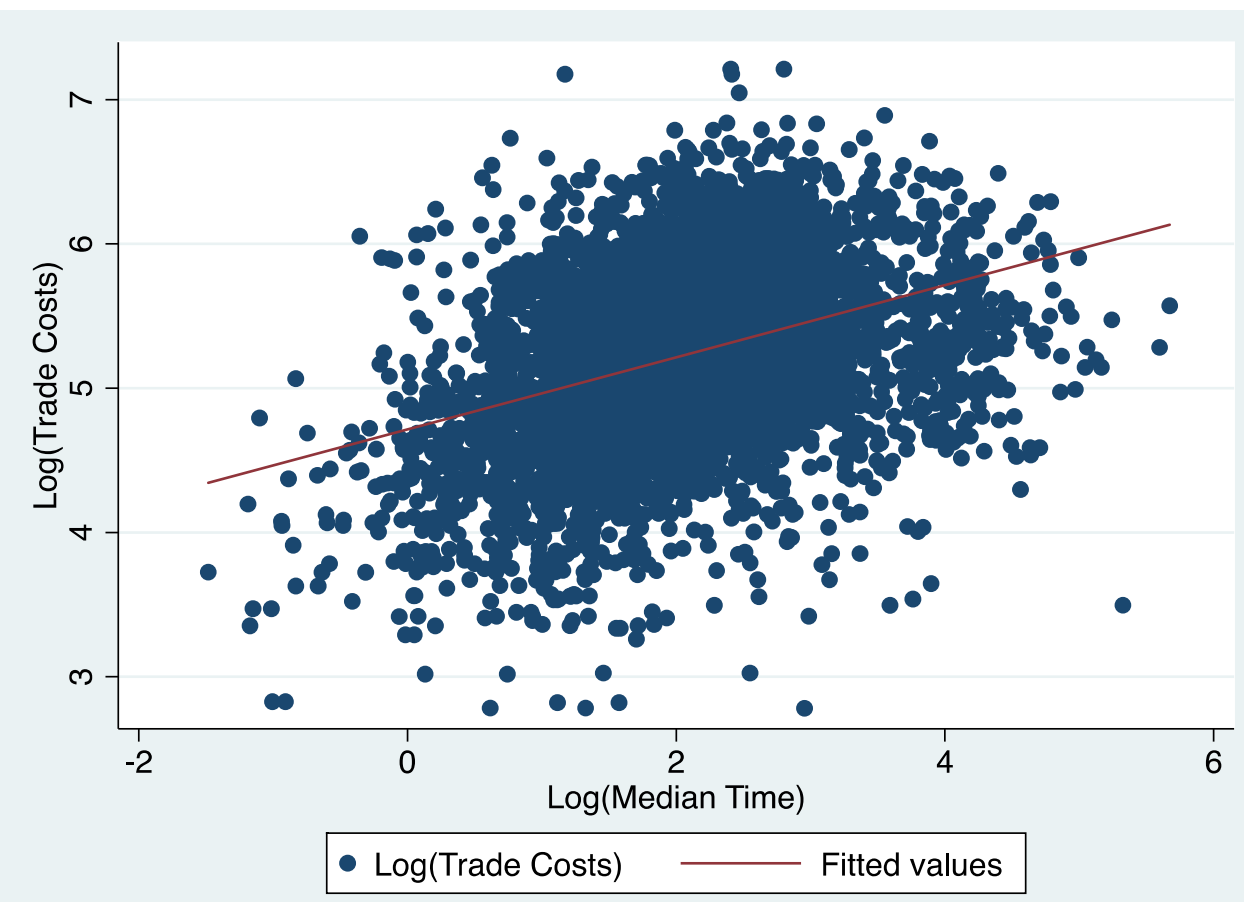

Source: Authors' calculations.

Figure 4: Correlation between Standard Deviation of Trade Time and Trade Costs (latest available year, all countries)

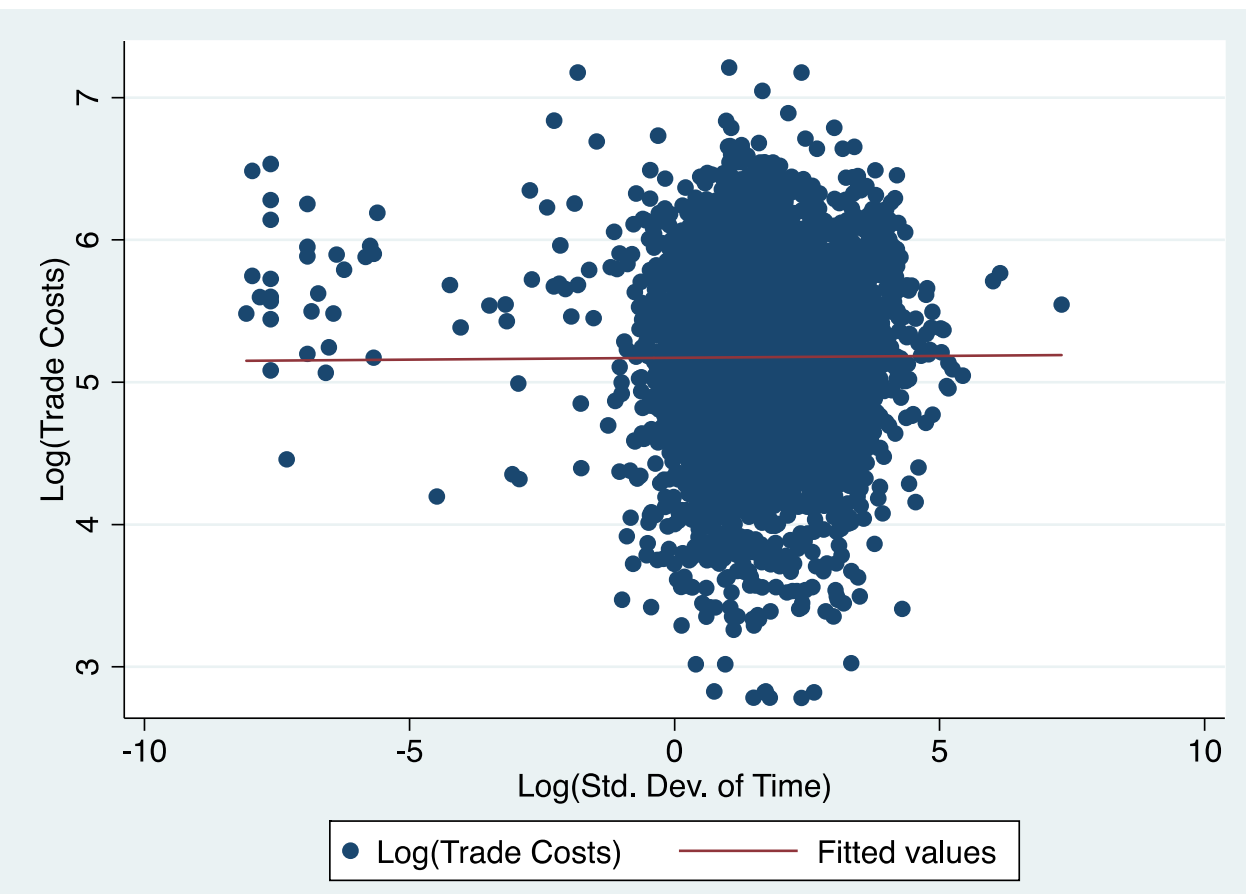




\section{ECONOMETRIC MODEL AND RESULTS}

18. We start the analysis by estimating a model with the bilateral country pair as the unit of analysis. Trade times are measured directionally, i.e., time to move goods from Australia to the United States (US) can be different from the time taken in the reverse direction. This characteristic of the data is quite realistic, as different routings and frequencies are common due to different traffic distributions across directional routes, particularly in maritime transport.

19. Our model takes the following form:

$$
\begin{aligned}
& \log \left(\text { trade cost }_{i j}\right) \\
&=d_{i}+d_{j}+b_{1} \log \left(\text { distance }_{i j}\right)+b_{2}{\text { RTA } A+b_{3} \text { CommonBorder }_{i j}} \\
&+b_{4} \text { SameCountry }_{i j}+b_{5} \text { CommonLanguage }_{i j}+b_{6} \text { Colony } \\
&+b_{7} \text { CommonColonizer }+b_{8} \log \left(\text { mediantime }_{i j}\right)+b_{9} \log \left(\text { sdtime }_{i j}\right) \\
&+b_{10} \log \left(\text { mediantime }_{i j} * \text { sdtime }_{i j}\right)+e_{i j}
\end{aligned}
$$

where the $d$ terms indicate full sets of exporter ( $i$ ) and importer ( $j$ ) fixed effects, RTA is a dummy variable equal to one if a regional trade agreement is in force for a given country pair, common border is a dummy equal to one if the two countries share a land border, same country is a dummy equal to one for countries once part of the same countries, common language is a dummy for country pairs with a common ethnographic language, colony is a dummy equal to one if one country was once a colony of the other, and common colonizer is a dummy equal to one if the two countries were once colonized by the same power. The final variables are our time data points, discussed in detail above. We include them in levels and also in an interaction term. Table 2 provides the summary statistics for the bilateral sample, and Table 3 provides the correlation matrix.

Table 2: Summary Statistics (bilateral sample)

\begin{tabular}{lccccc}
\hline \multicolumn{1}{c}{ Variable } & $\begin{array}{c}\text { Number of } \\
\text { Observations }\end{array}$ & Mean & $\begin{array}{c}\text { Standard } \\
\text { Deviation }\end{array}$ & Minimum & Maximum \\
\hline RTA & 18,441 & 0.209 & 0.407 & 0.000 & 1.000 \\
\hline Common Border & 18,338 & 0.022 & 0.148 & 0.000 & 1.000 \\
\hline Common Language & 18,338 & 0.143 & 0.350 & 0.000 & 1.000 \\
\hline Colony & 18,338 & 0.016 & 0.127 & 0.000 & 1.000 \\
\hline Common Colonizer & 18,338 & 0.083 & 0.276 & 0.000 & 1.000 \\
\hline Same Country & 18,338 & 0.010 & 0.0997 & 0.000 & 1.000 \\
\hline Log(Distance) & 18,338 & 8.648 & 0.813 & 4.088 & 9.894 \\
\hline Log(Median Time) & 8,666 & 2.030 & 0.890 & -1.482 & 5.673 \\
\hline Log(SD Time) & 7,669 & 1.675 & 1.282 & -8.077 & 7.301 \\
\hline Log(Median Time) ${ }^{*} \operatorname{Lgg}(S D)$ & 7,669 & 3.741 & 3.805 & -0.420 & 24.950 \\
\hline Log(Trade Costs) & 11,563 & 5.390 & 0.600 & 2.780 & 7.257 \\
\hline RTA & & & & & \\
\hline
\end{tabular}

RTA = regional trade agreement, $\mathrm{SD}=$ standard deviation.

Source: Authors' calculations. 
Table 3: Correlation Matrix (bilateral sample)

\begin{tabular}{|c|c|c|c|c|c|c|c|c|c|c|}
\hline & $\begin{array}{c}\log \\
\text { (Distance) }\end{array}$ & RTA & $\begin{array}{c}\text { Common } \\
\text { Border }\end{array}$ & $\begin{array}{l}\text { Same } \\
\text { Country }\end{array}$ & $\begin{array}{l}\text { Common } \\
\text { Language }\end{array}$ & Colony & $\begin{array}{l}\text { Common } \\
\text { Colonizer }\end{array}$ & $\begin{array}{l}\text { Log } \\
\text { (Median } \\
\text { Time) }\end{array}$ & $\begin{array}{c}\text { Log } \\
\text { (SD } \\
\text { Time) }\end{array}$ & $\begin{array}{c}\log \\
\text { (Median Time)* }^{*} \\
\text { Log(SD Time) }\end{array}$ \\
\hline Log(Distance) & 1.0000 & & & & & & & & & \\
\hline RTA & -0.4985 & 1.0000 & & & & & & & & \\
\hline Common Border & -0.3937 & 0.2047 & 1.0000 & & & & & & & \\
\hline Same Country & -0.2615 & 0.1462 & 0.3176 & 1.0000 & & & & & & \\
\hline $\begin{array}{l}\text { Common } \\
\text { Language }\end{array}$ & -0.0759 & 0.0793 & 0.1264 & 0.1262 & 1.0000 & & & & & \\
\hline Colony & -0.0576 & 0.0543 & 0.0915 & 0.0496 & 0.2186 & 1.0000 & & & & \\
\hline $\begin{array}{l}\text { Common } \\
\text { Colonizer }\end{array}$ & -0.1175 & 0.0090 & 0.0781 & 0.1049 & 0.2488 & -0.0533 & 1.0000 & & & \\
\hline $\begin{array}{l}\text { Log } \\
\text { (Median Time) }\end{array}$ & 0.4375 & -0.2969 & -0.1203 & -0.0986 & -0.0177 & -0.0945 & 0.0093 & 1.0000 & & \\
\hline Log(SD Time) & 0.2271 & -0.1502 & -0.01 & -0.0332 & 0.0321 & 0.0121 & -0.0011 & 0.4083 & 1.0000 & \\
\hline $\begin{array}{l}\log (\text { Median } \\
\text { Time)* Log(SD } \\
\text { Time) }\end{array}$ & 0.3013 & -0.1985 & -0.0536 & -0.0540 & 0.008 & -0.0398 & -0.0018 & 0.7059 & 0.8478 & 1.0000 \\
\hline
\end{tabular}

RTA = regional trade agreement, $\mathrm{SD}=$ standard deviation.

Source: Authors' calculations.

20. Table 4 presents the results. Each column adds a new time variable, and the final one introduces them all together. First, we can see that results on the control variables are robust and in line with expectations. Having a common border or language, having once been in a colonial relationship, and having had a common colonizer are all associated with lower trade costs (effects that are statistically significant at the $1 \%$ level). Similarly, larger bilateral distances are associated with higher trade costs, an effect that is also statistically significant at the $1 \%$ level. The variable for median trade time has the expected negative sign, and is statistically significant in all three regressions in which it is included. In terms of magnitude, its coefficient suggests that a 10\% increase in international transport time is associated with an increase in trade costs of $3.5 \%-4.9 \%$.

21. The results on uncertainty, by contrast, are not in line with expectations. The coefficient on the standard deviation of time has an unexpected negative coefficient, which is statistically significant in two of the three regressions. In the final regression with all-time variables entered, neither the standard deviation of time nor its interaction with median time has statistically significant coefficients.

22. We conclude from these results that there is robust evidence that longer trade times are associated with higher trade costs. However, we cannot conclude that less certain trade times are similarly connected with higher trade costs, as results are contrary to theoretical expectations, and may be linked to issues of data quality and quantity in the underlying indicators. 
Table 4: Regression Results (bilateral sample)

\begin{tabular}{|c|c|c|c|c|c|}
\hline & 1 & 2 & 3 & 4 & 5 \\
\hline \multirow[t]{2}{*}{ Log(Distance) } & $0.328^{* * *}$ & $0.315^{* * *}$ & $0.331^{* * *}$ & $0.318^{* * *}$ & $0.317^{* * *}$ \\
\hline & $(0.000)$ & $(0.000)$ & $(0.000)$ & $(0.000)$ & $(0.000)$ \\
\hline \multirow[t]{2}{*}{ RTA } & $-0.150^{* * *}$ & $-0.147^{* * *}$ & $-0.148^{* * *}$ & $-0.144^{* * *}$ & $-0.143^{* * *}$ \\
\hline & $(0.000)$ & $(0.000)$ & $(0.000)$ & $(0.000)$ & $(0.000)$ \\
\hline \multirow[t]{2}{*}{ Common Border } & $-0.283^{* * *}$ & $-0.289^{* * *}$ & $-0.263^{* * *}$ & $-0.268^{* * *}$ & $-0.269^{* * *}$ \\
\hline & $(0.000)$ & $(0.000)$ & $(0.000)$ & $(0.000)$ & $(0.000)$ \\
\hline \multirow[t]{2}{*}{ Same Country } & -0.099 & -0.094 & -0.102 & -0.096 & -0.096 \\
\hline & $(0.218)$ & $(0.239)$ & $(0.208)$ & $(0.224)$ & $(0.225)$ \\
\hline \multirow[t]{2}{*}{ Common Language } & $-0.135^{* * *}$ & $-0.130^{* * *}$ & $-0.129^{* * *}$ & $-0.122^{* * *}$ & $-0.122^{* * *}$ \\
\hline & $(0.000)$ & $(0.000)$ & $(0.000)$ & $(0.000)$ & $(0.000)$ \\
\hline \multirow[t]{2}{*}{ Colony } & $-0.201^{* * *}$ & $-0.192^{* * *}$ & $-0.201^{* * *}$ & $-0.190^{* * *}$ & $-0.190^{* * *}$ \\
\hline & $(0.000)$ & $(0.000)$ & $(0.000)$ & $(0.000)$ & $(0.000)$ \\
\hline \multirow[t]{2}{*}{ Common Colonizer } & $-0.199^{* * *}$ & $-0.192^{* * *}$ & $-0.199 * * *$ & $-0.193^{* * *}$ & $-0.193^{* * *}$ \\
\hline & $(0.000)$ & $(0.000)$ & $(0.000)$ & $(0.000)$ & $(0.000)$ \\
\hline \multirow[t]{2}{*}{ Log (Median Time) } & & $0.035^{* * *}$ & & $0.043^{* * *}$ & $0.049^{* * *}$ \\
\hline & & $(0.000)$ & & $(0.000)$ & $(0.000)$ \\
\hline \multirow[t]{2}{*}{ Log(SD Time) } & & & $-0.008^{* *}$ & $-0.015^{* * *}$ & -0.009 \\
\hline & & & $(0.035)$ & $(0.000)$ & $(0.169)$ \\
\hline \multirow[t]{2}{*}{ Log(Median Time)*Log(SD Time) } & & & & & -0.003 \\
\hline & & & & & $(0.350)$ \\
\hline Observations & 6,601 & 6,601 & 5,964 & 5,964 & 5,964 \\
\hline $\mathrm{R}^{2}$ & 0.791 & 0.792 & 0.790 & 0.791 & 0.791 \\
\hline
\end{tabular}

RTA = regional trade agreement, SD = standard deviation.

Notes: Dependent variable is log(trade costs) in all cases. Regression is by ordinary least squares with robust standard errors clustered by country pair. Standard errors appear in parentheses below coefficient estimates. Statistical significance is indicated by ${ }^{*}(10 \%),{ }^{* *}$ (5\%), and ${ }^{* * *}(1 \%)$.

Source: Authors' calculations.

23. An additional aspect of the relationship between time and trade costs, which has not been examined in the literature, relates to the determinants of international shipping times. To provide some first evidence on this question, we estimate a second econometric model of the following form:

$$
\begin{aligned}
\log \left(\text { Time }_{i}\right)= & b_{0}+b_{1} \log \left(\text { GDP per capita }_{i}\right)+b_{2} \text { landlocked }_{i}+b_{3} \text { island }_{i}+b_{4} \log \left(\text { LPI }_{i}\right) \\
& +b_{5} \log \left(\text { Average Distance }_{i}\right)+e_{i j}
\end{aligned}
$$

24. The unit of analysis in this case is the country, not the country pair. We, therefore, need to aggregate bilateral variables such as our time measures and distance. For the former, we apply two schemes alternatively: a simple average across partner countries, and a gross domestic product (GDP)weighted average across partner countries. For the dependent variable, we use different measures of time. Since we have access to transaction-level data, for each importing country, the median and standard 
deviation of the time taken for parcels from each of the source (exporting) country are calculated (this is the same as the bilateral data used above). From the bilateral data, for each importing country, average of median time and average of standard deviation are calculated. Averages used are simple averages and GDP-weighted across all source countries in the UPU data. For distance, we use a simple average across all countries in the world irrespective of whether they are in the UPU data or not. The sample size for this set of regressions is necessarily greatly reduced, so we keep explanatory variables to a minimum. The sample size is further reduced as we also drop observations in the top and bottom percentiles of the dependent variable used. Table 5 provides the summary statistics for the country-level sample.

Table 5: Summary Statistics (country sample)

\begin{tabular}{lccccc}
\hline \multicolumn{1}{c}{ Variable } & $\begin{array}{c}\text { Number of } \\
\text { Observations }\end{array}$ & Mean & $\begin{array}{c}\text { Standard } \\
\text { Deviation }\end{array}$ & Minimum & Maximum \\
\hline Log(GDP per capita) & 128 & 9.37 & 1.19 & 6.66 & 11.74 \\
\hline Landlocked & 131 & 0.20 & 0.40 & 0.00 & 1.00 \\
\hline Island & 131 & 0.17 & 0.38 & 0.00 & 1.00 \\
\hline Log(LPI) & 116 & 1.09 & 0.18 & 0.48 & 1.42 \\
\hline Log(Ave. Distance) & 131 & 8.98 & 0.18 & 8.78 & 9.49 \\
\hline Ave. Median & 119 & 12.47 & 4.09 & 3.42 & 25.79 \\
\hline Ave. SD & 118 & 10.27 & 4.44 & 4.25 & 41.24 \\
\hline W. Ave. Median & 119 & 12.21 & 4.87 & 4.15 & 28.74 \\
\hline W. Ave. SD & 118 & 12.03 & 5.24 & 5.36 & 49.13 \\
\hline
\end{tabular}

Ave $=$ average, $\mathrm{GDP}=$ gross domestic product, $\mathrm{LPI}=$ Logistics Performance Index, $\mathrm{SD}=$ standard deviation, $\mathrm{W}$. Ave = weighted average.

Source: Authors' calculations.

25. The variables included in the model are quite standard. We include GDP per capita as a control for development level, geographical characteristics as controls for remoteness from major markets, and the overall LPI is our variable of interest: we expect that superior logistics performance will be correlated with shorter international transport times, and greater reliability.

26. The results are provided in Table 6. Column 1 shows that some explanatory variables have considerable power in terms of explaining median international transport times. Specifically, the LPI is a strong predictor of international transport times: a higher score on the index is associated with lower transport times, an effect that is statistically significant at the $5 \%$ level. Control variables have the expected sign but, with the exception of distance in the first regression and GDP per capita in the third regression, are not statistically significant. The LPI variable in the third regression is marginally insignificant with a $p$-value of 0.11, but GDP per capita is negative and significant; it could be the case that the two are correlated. 
Table 6: Regression Results (country sample)

\begin{tabular}{lcccc}
\hline & Ave. Median & Ave. SD & W. Ave. Median & W. Ave. SD \\
\hline Log(GDP per capita) & -0.734 & -0.450 & $-1.191^{*}$ & -0.301 \\
\hline & $(0.153)$ & $(0.282)$ & $(0.083)$ & $(0.493)$ \\
\hline Landlocked & 0.286 & 0.357 & -1.550 & -0.723 \\
\hline & $(0.740)$ & $(0.584)$ & $(0.135)$ & $(0.444)$ \\
\hline Island & 1.193 & 1.992 & 1.515 & -0.857 \\
\hline Log(LPI) & $(0.204)$ & $(0.178)$ & $(0.235)$ & $(0.411)$ \\
\hline & $-6.424^{* *}$ & -0.967 & -5.653 & -0.194 \\
\hline Log(Average Distance) & $(0.034)$ & $(0.723)$ & $(0.114)$ & $(0.953)$ \\
\hline & $5.857^{* * *}$ & 1.562 & 0.415 & -2.647 \\
\hline Constant & $(0.000)$ & $(0.237)$ & $(0.838)$ & $(0.162)$ \\
\hline & $-26.495^{*}$ & 0.958 & 25.881 & $38.923^{* *}$ \\
\hline Observations & $(0.075)$ & $(0.937)$ & $(0.193)$ & $(0.026)$ \\
\hline$R^{2}$ & 108 & 107 & 109 & 107 \\
\hline Ave & 0.354 & 0.093 & 0.217 & 0.032 \\
\hline
\end{tabular}

Ave = average, GDP = gross domestic product, LPI = Logistics Performance Index, W. Ave = weighted average.

Notes: Dependent variable is indicated at the top of each column. Regression is by ordinary least squares with robust standard errors. Standard errors appear in parentheses below coefficient estimates. Statistical significance is indicated by ${ }^{*}(10 \%),{ }^{* *}(5 \%)$, and ${ }^{* * *}$ $(1 \%)$.

Source: Authors' calculations.

27. Models perform noticeably less well in the case of time uncertainty. None of the predictors have a statistically significant coefficient, so our ability to draw inferences about the contributing factors to greater reliability is correspondingly limited.

28. Although these results are weaker than might have been hoped on the variables of interest, this is not surprising in light of the relatively small sample. Indeed, Hillberry and Zhang (2015), who looked at the links between the Organisation for Economic Co-operation and Development's Trade Facilitation Indicators and time in customs, frequently found coefficients that were not statistically significant, and like us, heavily constrained by sample size and a cross-sectional setting.

\section{CONCLUSION AND POLICY IMPLICATIONS}

29. How do SASEC countries stand to benefit from improving trade facilitation to reduce international shipment times, and improve uncertainty? Although our models are not informative on the latter question, we do have strong results on the former, which we can use to perform counterfactual simulations. Concretely, we consider the reduction in each SASEC country's trade costs with the US if it were to reduce its international transport time to that country to the same level as the PRC's international transport time to the US. The results indicate that the gains could be substantial: by just over $5 \%$ for Bangladesh, by $2.7 \%$ for Bhutan, by $1.5 \%$ for Maldives, and by $0.5 \%$ for Sri Lanka. India's and Nepal's 
international transport times to the US are already lower than what is observed for the PRC; however, we caution that these results do not seem plausible and possibly reflect severe reporting problems in those countries.

30. These numbers show that potential welfare and efficiency gains from improving international transport times are economically significant. Although we have not simulated trade effects, existing results in the literature, such as Djankov, Freund, and Pham (2010), suggest that an extra day of transport time tends to reduce bilateral trade by about $1 \%$. Given that the differences we are finding are large in proportional terms, the potential to boost trade significantly by improving international shipment times is substantial.

31. In policy terms, our results suggest that SASEC countries need to concentrate additional resources on boosting connectivity. This means having infrastructure of sufficient quantity and quality that international shippers have an incentive to put in place a direct linkage. Indirect linkages and the need for transshipment significantly increase time, cost, and uncertainty, and can act as a drag on trade. Although some international gateways in SASEC countries perform well, none of them are close to the world technological frontier. 


\section{REFERENCES}

Anson, J., J.-F. Arvis, M. Boffa, M. Helble, and B. Shepherd. 2017. Time, Uncertainty, and Trade Flows. ADBI Working Paper. 673. Tokyo: Asian Development Bank Institute.

Anson, J., M. Boffa, and M. Helble. 2014. A Short-Run Analysis of Exchange Rates and International Trade with an Application to Australia, New Zealand, and Japan. ADBI Working Paper. 471. Tokyo: Asian Development Bank Institute.

Arvis, J.-F., Y. Duval, B. Shepherd, C. Utoktham, and A. Raj. 2016. Trade Costs in the Developing World: 1996-2010. World Trade Review. 15 (3). pp. 451-474.

Djankov, S., C. Freund, and C. Pham. 2010. Trading on Time. Review of Economics and Statistics. 92 (1). pp. 166-173.

Hillberry, R., and X. Zhang. 2015. Policy and Performance in Customs: Evaluating the Trade Facilitation Agreement. Policy Research Working Paper. No. 7211. Washington, DC: World Bank. 


\section{Trade Costs, Time, and Supply Chain Reliability}

This paper uses measures of international transport time in median and standard deviation based on shipment-level data from the Universal Postal Union, to analyze the effect of time on trade costs. The results show that median shipping times increase trade costs by a substantial amount. The determinants of shipping times are also analyzed and find that geographical distance is the most reliable indicator of median time and uncertainty, with logistics performance also playing a role in determining shipment times.

\section{About the Asian Development Bank}

ADB's vision is an Asia and Pacific region free of poverty. Its mission is to help its developing member countries reduce poverty and improve the quality of life of their people. Despite the region's many successes, it remains home to a large share of the world's poor. ADB is committed to reducing poverty through inclusive economic growth, environmentally sustainable growth, and regional integration.

Based in Manila, ADB is owned by 67 members, including 48 from the region. Its main instruments for helping its developing member countries are policy dialogue, loans, equity investments, guarantees, grants, and technical assistance. 